Abstract

\title{
The Use of Analysis of Weather Types to Complete the Studies of Soil Erosion in Vineyards and Abandoned Areas ${ }^{\dagger}$
}

\author{
Jesús Rodrigo-Comino 1,* , José María Senciales González ${ }^{2}$, José Damián Ruiz-Sinoga ${ }^{2}$ and \\ Johannes B. Ries ${ }^{3}$ \\ 1 Soil Erosion and Degradation Research Group, Department of Geography, University of Valencia, \\ Avda. Blasco Ibáñez, 28, 46010 Valencia, Spain \\ 2 Department of Geography, Málaga University, Campus of Teatinos s/n, 29071 Málaga, Spain; \\ senciales@uma.es (J.M.S.G.); sinoga@uma.es (J.D.R.-S.) \\ 3 Physical Geography, University of Trier, 54286 Trier, Germany; riesj@uni-trier.de \\ * Correspondence: rodrigo-comino@uma.es \\ † Presented at TERRAenVISION 2019, Barcelona, Spain, 2-7 September 2019. \\ Published: 20 December 2019
}

\begin{abstract}
This presentation aims to quantify water and soil losses due to rainfall and specific soil management practices in combination with an analysis of which kind of weather type and rainfall event is able to cause specific surface flows and soil loss rates. As study area, we used the specific case of the sloping vineyards of the Montes de Málaga (South Spain). Two different plots were used: one cultivated area and poorly managed abandoned one. The in situ measures were conducted using sediment collectors to estimate sediment yield $\left(\mathrm{g} \cdot \mathrm{m}^{-1}\right)$ and surface runoff $\left(\mathrm{L} \cdot \mathrm{m}^{-1}\right)$ and an analysis of the weather conditions during each rainfall event using different meteorological sources. The weather types that generated the highest amount of rainfall on the studied area came from the western $(32.6 \%)$ and southeast $(28.2 \%)$ types. The less rainy weather type came from the south type $(5.9 \%)$ and at the $500 \mathrm{hPa}$ level. On the other hand, the heaviest rains came from the southwest $(47.7 \%)$ and south $(34.1 \%)$. As a first approach, it is confirmed that there is a bimodality in rainfall patterns. The results of soil erosion showed that there is a mixed mechanism depending on the state of the soil (vegetation cover, compaction, initial soil moisture), soil management (tillage, trampling effect and the use of herbicides) and the intensity of the surface flow, which is highly correlated to the total rainfall amount and intensity. In the poorly managed abandoned vineyard, the impact of the tillage in the past, the elimination of the vegetation cover to conserve the bare soil and its use as a grazing territory by cultivating barley, highly impacts on the generation of the highest erosive events.
\end{abstract}

Keywords: soil erosion; vineyards



(C) 2019 by the authors. Licensee MDPI, Basel, Switzerland. This article is an open access article distributed under the terms and conditions of the Creative Commons Attribution (CC BY) license (http://creativecommons.org/licenses/by/4.0/). 